UDC 311.21:[311.174:336.761.5](569.4)

JEL Classification: C22, E44, H54

Doi: 10.31767/su.1(92)2021.01.08

\author{
N. V. Agabekova, \\ Dr. habil., Associate Professor, \\ Chair of the Department of Statistics, \\ E-mail: agabnin@mail.ru \\ ORCID: https://orcid.org/0000-0002-4315-7177; \\ A. N. A. Abdo, \\ PhD Student, \\ E-mail: nasserdineabdo@gmail.com \\ ORCID: https://orcid.org/0000-0002-4092-1037; \\ Educational Institution "Belarus State Economic University" (Minsk, Belarus)
}

\title{
Economic and Statistical Analysis of Stock Market Performance in Lebanon
}

Analysis of financial processes is an important and fast developing branch of statistics. Statistical analysis is a combined analysis. Statistical methodology refers to a system of techniques and methods aimed at studying quantitative patterns in the dynamics and relationships of socio-economic phenomena. The main feature of the statistical methodology is also the specificity of research, expressed in the inextricable connection of quantitative analysis with the establishment of a qualitative uniqueness of objects in the concrete historical conditions of place and time. The use of the techniques of mathematical statistics and other branches of mathematics (applied, in particular) becomes a technical means of implementation.

Lebanese stock market today is inactive and is shrinking. Historically, Lebanon had a relatively vibrant capital market in the Middle East before the stock exchange was closed for twenty years due to the civil war (1975-1995). Since its reopening in 1996, the stock market has been contracting. The establishment of Solidere in late 1990s and the renaissance of commercial banks energized the stock market for a while before the volatility of the market hold back.

The article analyzed the change in the main indicators of the Lebanese stock market for the period from 2012 to 2019. The study developed a statistical model for the decomposition of time series, which was led to identify the trend, seasonal, cyclical and random components.. The simulation results made it possible to establish the patterns of changes in the share prices of the three leading enterprises representing the construction, industrial and banking sectors of the Lebanese economy. The length and depth of short-period cycles in the studied indicators time series were measured. It was found that the depth of cyclical fluctuations increases with decreasing stock prices of Lebanon's construction and industrial enterprises under the influence of both economic and political processes, while the cyclic recurrence of stock prices in the banking sector was less pronounced and was mainly determined by changes in the economy

Key words: stock market, statistical analysis, decomposition of time series, short-period cycles, components of time series, Lebanese economy.

Introduction. The Lebanese stock market belongs to the category of frontier market, which is a type of developing country that is more developed then the least developing countries, but too small, risky or illiquid to be considered an emerging market.

Like every item in life, the stock market has its advantages and disadvantages. Of the advantages, this provides a platform for buyers and sellers to meet, to trade assets, investors can easily sell their securities and convert them into cash, thereby providing liquidity for traded assets. Some of the shortcomings, there are certain factors that suddenly change the price of securities. Thus, there is a risk associated with trading in the financial market. For example, if there is any negative news about the company, its price may decrease significantly, which

(C) N. V. Agabekova, A. N. A. Abdo, 2021 will lead to losses for the person owning its shares, and prices in the financial market may not indicate the true intrinsic value of the shares due to some macroeconomic factors, such like taxes.

However, in order to avoid and reduce the risk when trading in stock markets, there are several statistical models according to which a trader can use them to forecast future prices, he can also study the influence of many economic factors, such as interest rate, unemployment rate, GDP, Inflation and other indicators. Good forecasts can reduce uncertainty about the future and therefore help buyers and sellers make better decisions.

The analysis of empirical financial series has a great influence on the forecast and investment decisions. Financial time series are constantly being brought to our attention. Daily news releases in newspapers on television and radio inform us, for 
example, about the latest stock market indices, exchange rates, electricity prices and interest rates. It is desirable to often monitor the behavior of these indicators and try to understand their possible future development.

There are two main goals of researching financial time series. First, it's important to discover, how financial market parameters behave. The second goal is to use our knowledge to make better forecast and reduce risk of wrong decisions.

In this article we focus our analysis on the price of shares of three different sectors of Lebanese economy, namely development and reconstruction, banking and industrial sector.

The paper is organized as following. Section 1 provides a literature review on the methods of stock market analysis, their comparison to implement an analysis of the stock market performance in Lebanon. In Section 2 describes the data and outlines the models of decomposition of a time series. Section 3 discusses the results.

Literature review. In stock market domain there are several schools of strategies and analysis fundamental analysis, technical analysis and statistical modeling - that differ with the tools and instrument used in each one. Technical and fundamental analyses are the two main approaches to analyze the stock markets $[1 ; 2]$

Fundamental analysis seeks to understand the stock market performance by analyzing economic, social, and political forces that affect the supply of and demand for it such that economic growth, annual report, balance sheet, capital flows, trade flows, balance of trade, inflation rates, unemployment rates and political stability. Traders who utilize fundamental analysis study the news for information on political climate, international relations, natural disasters and other events to determine what to expect in the currency market. In the stocks market, fundamental analysis is defined as a technique that attempts to determine a security's value by focusing on underlying factors that affect a company's actual business and its future prospects [3]. Ou and Penman suggested that abnormal return can be predicted by using fundamental analysis [4]. Political considerations influence the level of confidence in a nation's government, the climate of stability, and level of certainty [5]. According to $\mathrm{Hu}$ et al. [6], fundamental analysis is mainly based on three essential aspects: macroeconomic analysis such as Gross Domestic Product (GDP) and Consumer Price Index (CPI) which analyses the effect of the macroeconomic environment on the future profit of a company, industry analysis which estimates the value of the company based on industry status and prospect, and company analysis which analyses the current operation and financial status of a company to evaluate its internal value.
From fundamental view, in Lebanon, the political unpredictability is perceived by economists as the most important problem for economic growth. It leads to an increase in the market volatility, a decrease in the investment level and thus can negatively affect the stock 1 market performance and the investors and especially the foreign ones will be less confident in the Lebanese stock market. Since 2012 many political problems and crises have occurred in Lebanon and have affected the Lebanese stock market, especially the trading in the BSE which is the only stock market in Lebanon, starting by the civil war in Syria that created the refugee problem in Lebanon from 2012 till present, the resignation of the Lebanese government (March 2013), the terrorist attacks (2013), the country remained without President around 2 years (2014-2016). During the period 2012 till 2019 the economic growth was decreased and the Lebanese debt increased to 80 USD Billion in 2019 from 57 USD Billion in 2012. In 17 October 2019 the revolution started against the economic and political corruption which exist from 30 years old and pushed the government to resign. The instability in the political and economic situations that Lebanon undergoes lead to decreasing trend of Lebanon equity market index (BDLSI) from a value of 136.52 on January 2012 to a value of 52.31 on December 2019 [7].

Lebanon lives for several decades of political instability, and every time it is offered for any sudden accident that makes a fundamental analysis in the long term done for any company and for the economic situation as a whole is wasted.

In the other side, the technical analysis based on historical and statistical data, help us to predict the future prices of stocks and evaluate the performance of the stock market. Technical analysis is a shorthorizon trading method; positions last a few hours or days.

Technical analysis is a method to predict movement of stock price by using techniques such as pattern recognition analysis and chart analysis without referring to economic or fundamental analysis [8]. Technical analysis (sometimes alternatively referred to as chartist analysis) is a set of techniques for deriving trading recommendations for financial assets by analyzing the time-series history of the particular asset price either graphically or mathematically [9]. The field of technical analysis relies on the three assumptions holding true: 1) the markets discount everything, that is all information is already incorporated in the price of the security; 2) price move in trends; 3) history repeats itself [10]. Based on these axioms, a large number of indicators and methods have been formed that are used to determine the moments of buying and selling financial assets in order to derive market profit. 
There is some evidence that technical analysis has predictive power on stock return. W. Brock, J. Lakonishok and B. LeBaron [11] examined two trading rules which are moving average and trading range break on the Dow Jones Industrial Index from 1897 to 1986. A. J. Hejase, School of Business, Islamic University of Lebanon [12] examined the ability of basic Technical analysis tools to forecast security prices within the Lebanese stock market. Moving Average and Relative Strength Index (RSI) variants were used to assess the capabilities of Technical analysis against the efficient market hypothesis represented by a Buy/ Hold strategy. The results demonstrate that long (100 days), medium (50 days) and short (10 days) term Moving Averages have significant predictive ability to forecast Lebanese banking and real estate stock prices when compared with their Buy/Hold competitors. Likewise, the study suggests that the application of RSI Technical Analysis variants on several Lebanese stocks have no predictive ability to outperform the Buy/Hold approach.

Technical analysis is based on the use of a single type of information, the predicted market prices of an asset, therefore it is impossible to assess the effect of other information with its help, which inevitably reduces its effectiveness and leads to the formation of erroneous forecasts for these assets when the associated dynamics of market assets and other indicators affects price trends.

Existing methods of technical analysis are not able to adaptively take into account changes in influencing factors in the forecasting process: firstly, they are basically not designed for this, and secondly, trading models do not change from the moment of optimization of internal parameters. As a result, the methods of technical analysis lose their effectiveness, since both situational and long-term changes occur in the nature of the influence of market information on the prices of the forecasted asset.

Over the past years, the researchers have been interested in studying of stock market performance and its trends to predict various outcomes by means of statistical modeling and the decomposition of time series in case of statistical forecasting [13; 14; 15]. The most efficient way to forecast is to understand the present scenarios. Considering the patterns in the time series is an important aspect in time series analysis as it helps in selection of statistical forecasting models

Material and Methods. Data and Sources of Data. This study is focused on the price of three shares of three different sectors, SOLA (Solidere Company, development and reconstruction sector), BYB (Byblos bank, Banking sector) and HOLC (Holcim Liban, industrial sector). The three companies were selected based upon the market capitalization by sectors of activities in the Beirut Stock Exchange (BSE) and their role on Lebanese economic development.
Solidere, The Lebanese Company for the Development and Reconstruction of Beirut Central District s.a.l., was found as a Lebanese jointstock company, on May 5, 1994. It is behind the reconstruction of the Beirut central district. Solidere's role is land developer, real estate developer, property owner, property and services management and operation. It is currently involved in projects in the United Arab Emirates, the Kingdom of Saudi Arabia, and Lebanon, and is exploring new opportunities in promising market. Solidere has two common traded shares on the BSE, SOLA and SOLB.

Byblos Bank is a Lebanese bank established in 1963 and headquartered in Beirut, Lebanon. It is the country's third largest bank by assets. Byblos Bank is listed on the Beirut Stock Exchange (BYB) and became in 2009 the first Lebanese issuer to be listed on the London Stock Exchange. It also actively operates in 9 countries in the Middle East, Europe, and Africa. Byblos Bank currently has three types of shares in circulation: common, global depositary receipts (GDRs) and preferred. While the common and preferred shares are traded on the Beirut Stock exchange, GDRs are traded on both the Beirut Stock Exchange and the London Stock Exchange. The analysis in this paper revolve around the common share traded in BSE, there is 565515040 Byblos Common Shares.

Holcim Liban SAL is a Lebanon-based company involved in the manufacture, treatment and distribution of cement and its derivatives. In addition, the Company also offers consulting, research, trading, engineering and other services. The Company's commercial and institutional projects include highrise buildings, business districts, and stadiums. The Company is a subsidiary of Switzerland-based Holcim Ltd. Its factories are situated in the North of Lebanon, and in Cyprus. It distributes its products in the local market as well as in the Middle East region. The company is present on BSE by one share which is HOLC.

The pertained data consists of the monthly closing prices and it is collected from the secondary sources viz. BSE official website [16]. The monthly share prices of above-mentioned companies are taken for a period between January 2012 to December 2019.

Model of decomposition time series. A time series consists of four components: long term trend, seasonal, cyclic and random component. In order to study correctly the trend, it is necessary to establish random and periodic fluctuations and find the residual deviations of the actual data from the estimated trend (general trend). This can be clearly represented in the form of a statistical model of short-period cycles (1):

$$
Y-Y_{t}=\left(Y-Y_{k}\right)+\left(Y_{k}-Y_{c}\right)+\left(Y_{c}-Y_{t}\right)
$$

where, $Y$ - the initial observed values; $Y_{k}$ - the smoothed value; $Y-Y_{k}$ - the random components; 
$Y_{c}$ - the seasonally adjusted values; $Y_{k}-Y_{c}-$ the residuals of the seasonal component; $Y_{t}$ - the estimated value by the trend estimation; $Y_{c}-Y_{t}-$ the residuals of the cyclic fluctuations.

In order to smooth the actual data $Y$ and eliminate the randomness, we use the Fourier series to find the smoothed data $Y_{k}$ then calculate the random component $E$ by subtracting the Fourier smoothed data from the actual data $\left(Y_{k}-Y=E\right)$.

In the study of phenomena of the periodic type, the following type of equation is use as an analytical form of development in time (2):

$$
\hat{Y}_{i}=a_{0}+\sum_{h=1}^{4}\left(a_{h} \cos h t+b_{h} \sin h t\right)
$$

where, $t$ - the angle in radian; $a_{h}, b_{h}$ - the regression coefficients; $a_{0}$ - the average value of the time series data of 12 months; $h$ - the harmonic of the series.

To find the coefficients $a_{0}, a_{h}$ and $b_{h}$ of the equation, the least squares method is used, so that

$$
\sum_{1}^{n}\left(Y_{i}-\hat{Y}_{i}\right)^{2}=\min , n=12,
$$

monthly data. We find the partial derivatives of this function then we determine the critical values by setting the partial derivatives equal to zero which gives the coefficients of the Fourier series (3):

$$
\left\{\begin{array}{l}
a_{0}={ }_{n}^{\mathrm{T}} \sum_{1}^{n} Y_{i} ; \\
a_{h}={ }_{n}^{2} \sum_{1}^{n} Y_{i} \cos h t_{i} ; \\
b_{h}={ }_{n}^{2} \sum_{1}^{n} Y_{i} \sin h t_{i} .
\end{array}\right.
$$

Another technique used in this study to exclude a random component is piecewise linear function or piecewise nonlinear function. This technique involves the construction of the best functions (trends) for each period for the studied period of time. Therefore, for monthly data, the number of such functions was 12 . To smooth the data for each month, various types of functions (linear, logarithmic, second and third order polynomials, etc) is tested. The selection of the best functions is carried out according to the criterion of the maximum reliability of the approximation $\left(R^{2}\right)$. The initial data for applying the piecewise model is presented in the form of a matrix of individual observations. Years are presented by line, and months by column. Each individual observation refers to the $k$-th month of the $j$-th year. Thus, there are 12 time series, each of which contains data for a separate month of the year. When modeling the dynamics of monthly indicators in the time factor scale, the coding of the time attribute in months is combined with annual units. Thus, in the time factor scale, the time is represented by both integer and fractional numerical designations (time gap 0.083).It should be expected that dynamics of monthly indicator is closely consistent with the general trend characteristic of the analyzed season.

In order to remove the seasonal fluctuations of the data and exclude their influences on the forecasting procedure, the methodology for eliminating the seasonality factor involve calculating the seasonality index following the formula (4)

$$
I_{c, i}=\bar{Y}_{i} / \bar{Y}
$$

where, $\bar{Y}_{i}$ - the average level for the each month (i); $\bar{Y}$ - the average level of the series for the entire period as a whole.

The elimination of the seasonality factor is done by dividing the smoothed value $\left(Y_{k}\right)$ by the seasonality index corresponding to each month. The result is data adjusted for the seasonality index, that is, free from the influence of the random and seasonality factors. However, such adjustment should not be limited if the received data do not coincide with the initial data for years. As a rule, such discrepancies are observed, and secondary correction is used to eliminate them. For this, the correction factor is calculated by dividing the actual (observed) annual profit indicators by the annual indicators of the adjusted levels. Mathematically, this adjustment is as follows: Initial adjustment (5):

$$
Y_{c 1}=Y_{k} / I_{c}
$$

where, $Y_{c 1}$ - the initially adjusted levels; $Y_{k}-$ the smoothed value; $I_{c}$ - the seasonality index.

The first adjustment is followed by a second adjustment to obtain the final adjusted values $Y_{c}(6)$ :

$$
Y_{c}=Y_{c 1} \cdot k=Y_{c 1} \cdot \frac{\sum Y_{k}}{\sum Y_{c 1}}=\frac{Y_{c 1}}{\sum Y_{c 1}} \cdot \sum Y_{k},
$$

where, $Y_{c}$ - the values after the secondary adjustment; $k$ - coefficient of secondary adjustment; $\sum Y_{k}-$ annual sum of the smoothed values; $\sum Y_{c_{1}}$ - the annual sum of the seasonally adjusted data in first time.

The seasonally adjusted data are used to determine the linear regression equation and to find the values $Y_{t}$ that helps us to identify the cycles by calculating residues $\left(\varepsilon=Y_{c}-Y_{t}\right)$.

The cyclic variation is due to the repeating up and down movements due to interactions of factors influencing economy. Before determine shortperiod cycles, we prove that our residues are not random with the turning point test for residues (see J. B. Cromwell, W. C. Labys, M. Terraza 1994, [18]). If there is no enough evidence to support the claim that the residues are independent (random), we determine 
the length short term cycles and derive their average depth by the following formula (7):

$$
s_{i}^{2}=\frac{\sum\left(\varepsilon-\varepsilon_{i \min }\right)}{n_{i}-1},
$$

where, $\varepsilon$-residues values; $\varepsilon_{i \text { min }}$ - minimum residual value in the cycle $i ; n_{i}$ - the length of the short-period cycle.

The occurrence of these cycles is also proved by considering the moving average (MA) of the residuals. The calculation in this article is done using
Microsoft Office Excel. All figures are based on the author's calculations.

Results and discussions. The Solidere share (SOLA) usually dominated the volume of trading on the Beirut Stock Exchange BSE, followed by the commercial banks.

The results of the time series decomposition were presented in the Figure 1: the actual closing prices at monthly time basis $(Y)$, the Fourier smoothed data $\left(Y_{k}\right)$, the seasonally adjusted values $\left(Y_{c}\right)$, and the estimated value by the linear trend estimation $\left(Y_{t}\right)$.

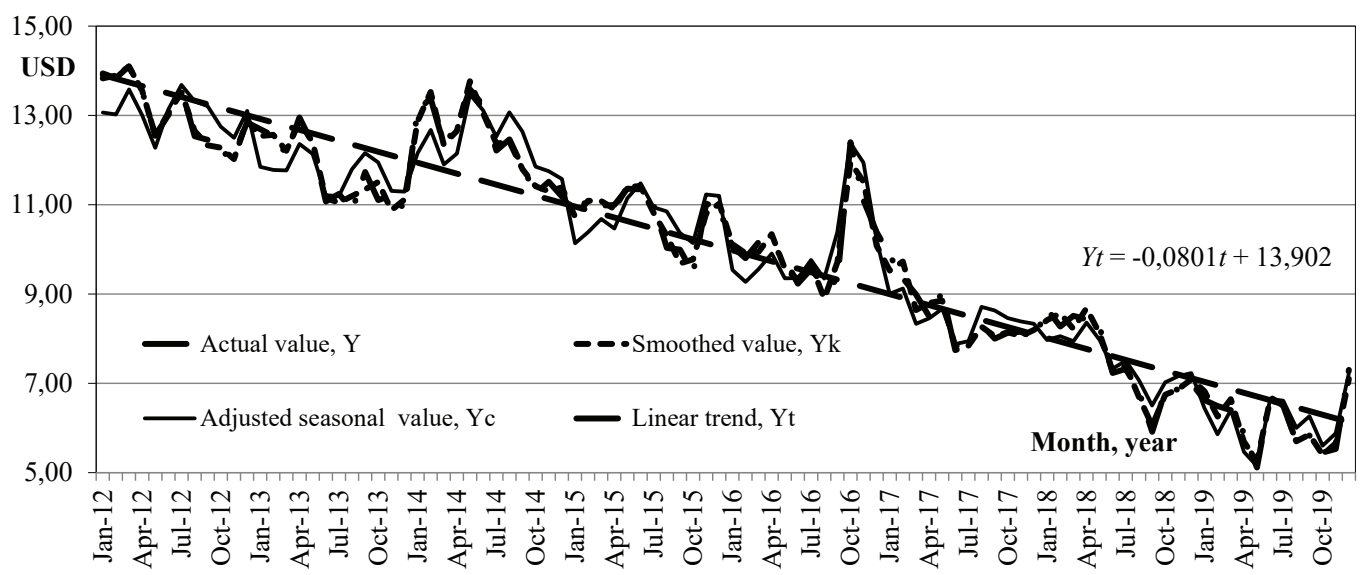

Figure 1. The results of the time series decomposition

The choice of the Fourier series as the smoothing method was due to the fact that the cyclic component was detected more clearly than with the piecewise functional method. The Seasonal Indexes of the Solidere share (SOLA) prices were shown in the Figure 2.

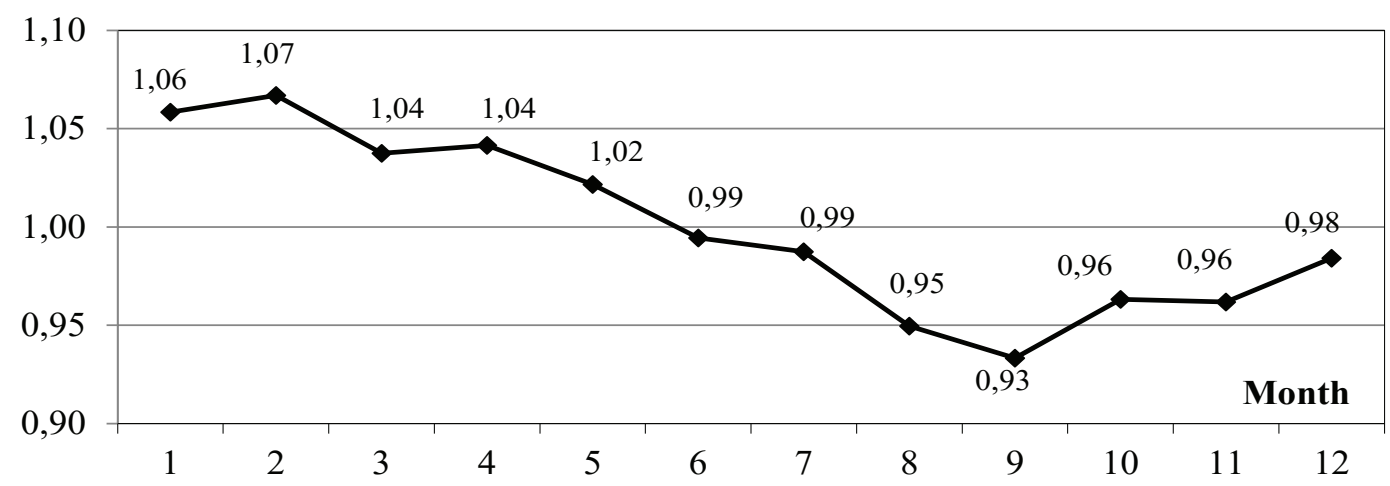

Figure 2. Seasonal index of SOLA share price

The seasonality of the SOLA share prices during the period of study indicated that there was a decrease in share price in September, which was the end of the summer season. In this month the construction projects slowed down in Lebanon and the tourism activities decreased.

The fluctuations of the residuals were shown in the Figure 3.

To reveal short-period cycles we needed to run turning point test first. Number of data points: $T=96$; number of turning points: $V=50$. The test statistics was:

$$
Z=\frac{|V-E(V)|}{\sigma_{V}}=\frac{\left|50-\frac{188}{3}\right|}{\sqrt{\frac{1507}{90}}} \approx 3.09 .
$$

The critical value according to the standard normal distribution $\mathrm{N}(0 ; 1) \tau=1.96,|z|>\tau$, so we rejected the null hypothesis $H_{0}$. There was no enough evidence to support the claim that the residuals were independent (random).

We identified three short-period cycles: the first cycle was between July 2012 and March 2014, the 
second cycle - between April 2014 and October 2016 and the third one - between November 2016 and December 2019. The occurrence of these cycles also was proved by considering the moving average 5 of the residuals as shown in the Figure 4.

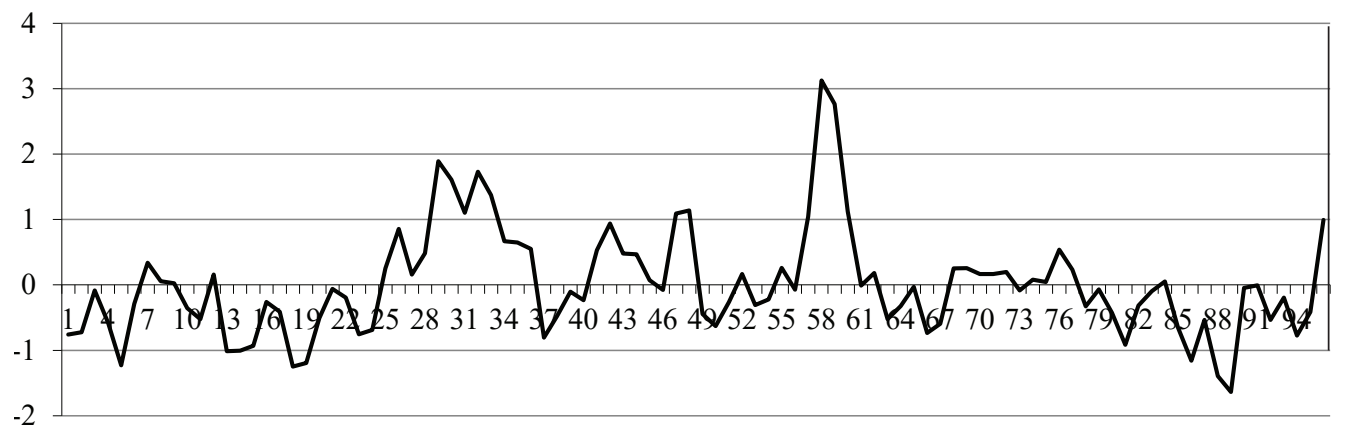

Figure 3. Fluctuations of the residuals $Y_{c}-Y_{t}$ from January 2012 till December 2019 (SOLA share prices)

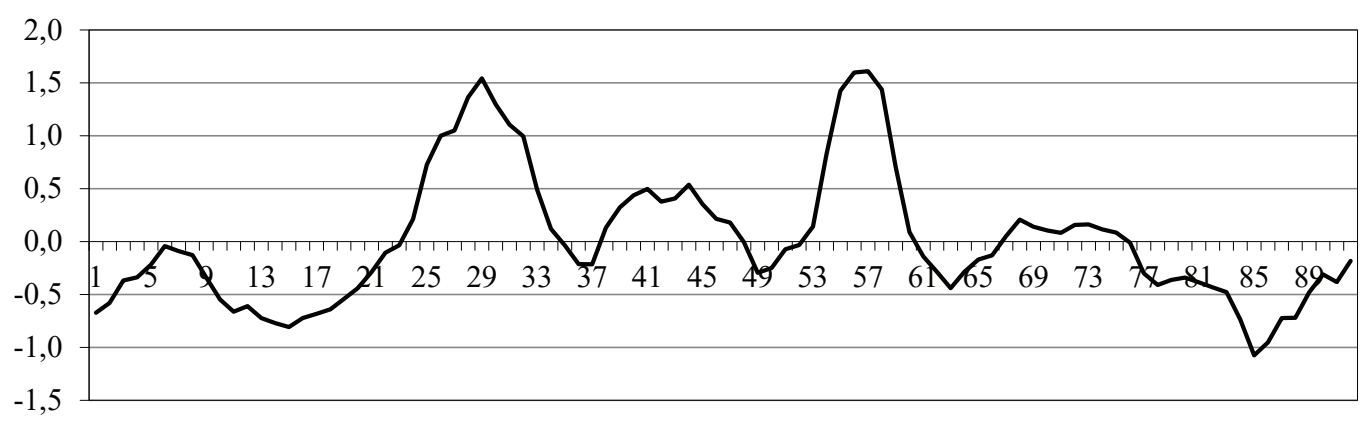

Figure 4. Moving average 5 of the residuals $Y_{c}-Y_{t}$

The calculation of the residual variances of each cycle of these data shown an increase in the average depth from cycle to the next one:

$$
S_{1}^{2}=1.25, S_{2}^{2}=2.09 \text {, and } S_{3}^{2}=3.40 \text {. }
$$

As the length of the cycle increases, the variance was larger.

The formation of these cycles matched with the political events in Lebanon, the first cycle started at July 2012 and ends March 2014 and passed through a recession level during 2013 where the government was resigned and the terrorist's attacks were at their peak level. The second cycle also was lied in the period where no president in Lebanon and reached its peak where there was a solution for the presidential problem. After the election of the new president Lebanon entered a new cycle and the an expansion level was started and the cycle ends in December 2019, in this period the country entered on a revolution on the political and the economic situations from October 2019. Some brokers said that many Lebanese businessmen preferred to buy stocks in New York, Paris or London as these shares generated more revenues for investors. Year after a year empty apartments, offices and stores in Beirut's Downtown had become a familiar sight since the outbreak of the Syria crisis over the past years till the
SOLA reached its historical monthly low at $\$ 5.14$ on May 2019.

The banking sector was considered the most important sector in Lebanon and one among the best banking sectors in the Middle East. Byblos bank had three types of shares, common, preferred and GDR. Here we took one of them, the most popular which was the common share. The decomposition of the time series of this share (the smoothed values, the seasonal adjusted values and the trend values) were calculated according to the same procedure of SOLA share. It was obtained downward trend $\left(Y_{t}=-0.0028 x+1.6865\right)$. The seasonal index ranged between 0.97 and 1.05 , these two extreme values were close to 1 , thus there were not big seasonal variations. We noticed that the index was greater than one for the first five months of the year and less than one for the remaining months. So the price was above the monthly average from January to May while it was below the monthly average from June to December. The fluctuations of the residuals were shown in the Figure 5.

The turning point test statistics $(Z)$ was 2.61 . Since $|z|>\tau(1.96)$ we rejected the null hypothesis $H_{0}$ that the residuals were random $(\alpha=0.05)$.

The BYB share admitted only one cycle from October 2012 till May 2018. It can be seen also from the moving average 7 of the residuals $Y_{c}-Y_{t}$ (Figure 6). 


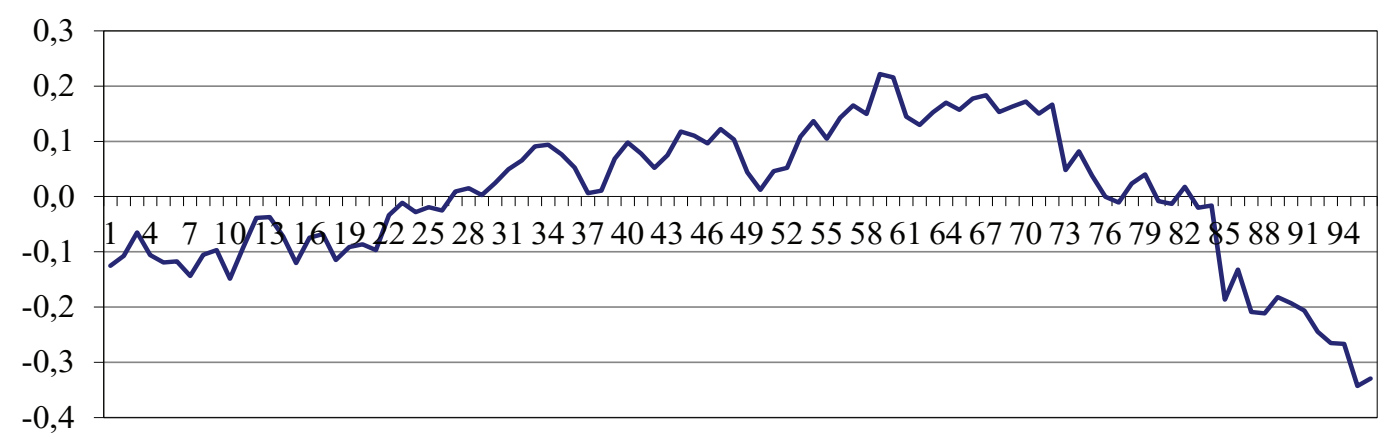

Figure 5. Fluctuations of the residuals $Y-Y$ from January 2012 till December 2019 (BYB common share prices)

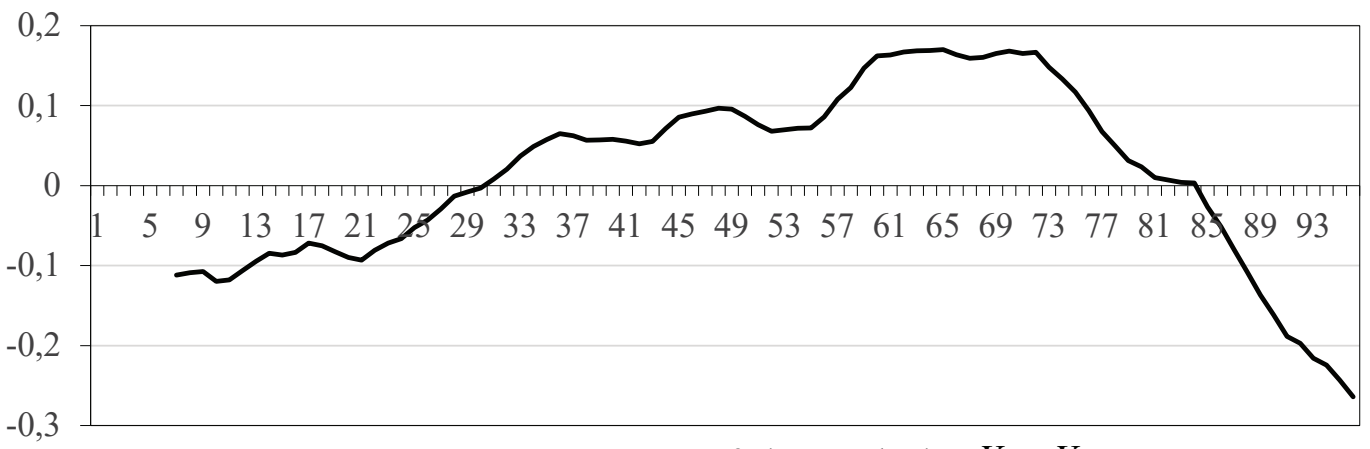

Figure 6. Moving average 7 of the residuals $\left(Y_{c}-Y_{t}\right)$

The Lebanese banking industry was financially sound and stable, it was a safe place for investors till April 2018 where a big economic problem started to appear and affected the banking sector. The investors lost some of their confidence in this sector, and they started to sell their shares and get out of the market, this reaction led to a big fall in BYB share price from $\$ 1.5$ per share in April 2018 to $\$ 1$ in December 2019, around a loss of $33.3 \%$ per share during 20 months.

HOLC share represented the industrial sector in the Lebanese stock market, the volume of trading of this share was less than the volume of trading of shares in banking and construction sectors. The observation of the time series of the HOLC share price showed a break in this time series due to a slowdown in the real estate sector in the first half of 2016, which impacted the liquidity flow negatively.

To verify the existence of this break in the time series, we conducted the Chow test to prove this break.

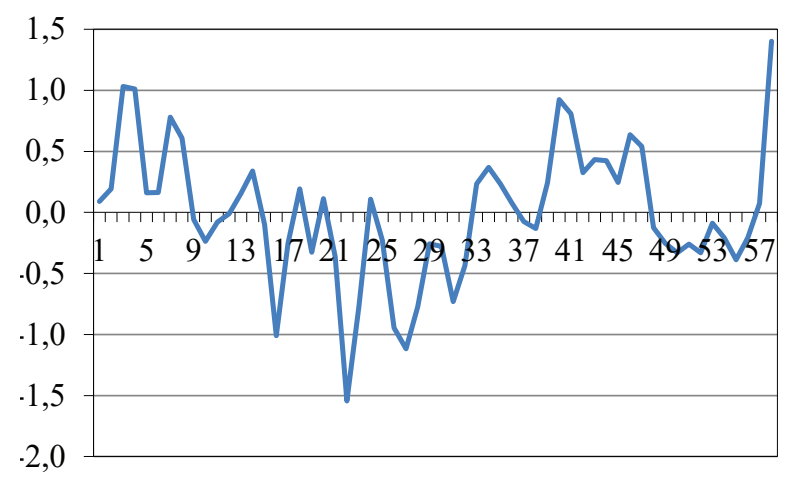

a) From January 2012 till October 2016
According to the calculation the null hypothesis was rejected, two groups had different slopes and intercepts and the main data were not poolable. The data was split into two groups, the first group from January 2012 (1) till October 2016 (58), the second group from November 2016 (59) till December 2019 (96). The calculation was done for every group of data alone, and the results of the decompositions were as follows: trend value for the first group of data; $Y_{t}=-0.0307 x+16.163$ for the second group of data $Y_{t}=-0.00008 x+13.648$. In both data, the seasonal index ranged between 0.95 and 1.05. It had shown a small seasonal variation, which was more 1 in the first half of the year and less 1 in the second half. Such patterns were due to high demand and export of cement, while this demand slowed down in the second half of the year.

The fluctuations of the residual were given in Figures 7 a) and b).

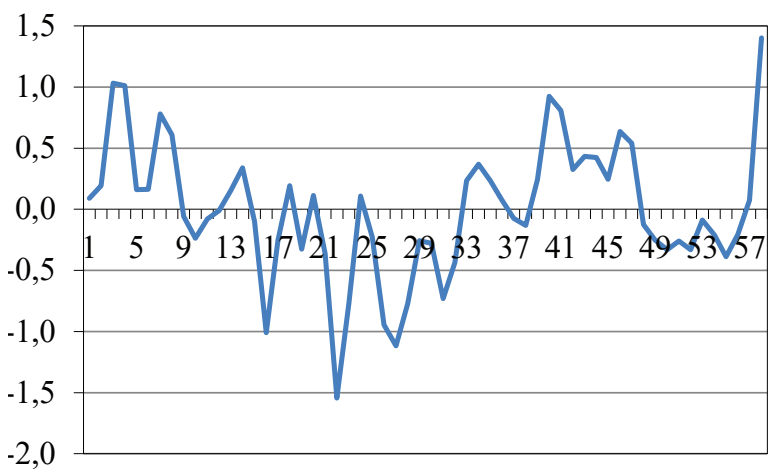

b) From November 2016 till December 2019

Figure 7. Fluctuations of residuals $Y_{c}-Y_{t}$ (HOLC share prices) 
The turning point test was ran and there was no enough evidence to support the claim that the residuals were independent $(Z \approx 3.58$, critical value $\tau=1.96, \alpha=0.0$ ).

According to the graph of residuals, there were two short-period cycles from January 2012 till October 2016, the first cycle ranged from March 2012 till April 2015, the second cycle ranged from May 2015 till October 2016. While in the second half of data, there is only one cycle from November 2016 till June 2019. The calculation of the residual variances of each cycle in the group showed an increase in the average depth from cycle to the next one:

$$
S_{1}^{2}=2.54, S_{2}^{2}=3.28 \text {, and } S_{3}^{2}=13.83 .
$$

These cycles were results of the political situation in Lebanon between 2012 and 2014, there were some terrorist attacks but the production and the construction sector was good and the export too especially to Syria and other countries, but between in 2015 and 2016 the country was lived without a president and suffered from political tension which form the second cycle, that started with a recovery of the price from $\$ 11.02$ per share to $\$ 17.34$ per share and ends with a fall of the price to $\$ 9.14$ per share following the protest movement against the poor economic situation. The third cycle coincided with the SOLA stock price cycle, which represented the construction sector, and had the same reasons.

Conclusion. The present study discussed the stock market performance in Lebanon from 2012 to 2019 using statistical method.

1. The presented model of time series decomposition revealed and explained the trend, seasonal and cyclical components of the construction, industrial and banking sectors stock prices in the Lebanese economy.

The results of this study showed that stock prices of all sectors of the economy were characterized by a decreasing trend. The patterns of seasonal fluctuations were revealed in the decline in stock prices in August and September, which gave an opportunity for investors to buy the share in these months and sell it later with a profit. An analysis of the cyclical component of the construction and industrial companies' stock prices time series showed that the depth of the cycle increased with decreasing stock prices. The stock price of the Lebanese banking sector, in contrast to the industrial and construction sectors, was affected less by the political events.

2. It was suggested that the results of economic and statistical analysis the Lebanese stock market performance made it possible to forecasting the stock prices. However, the suggestion made here may has certain limitation due to the fact that the study has been carried out with monthly data. The other significant limitation to reduce the wrong decisions risk was not to statistical assess the relationship between macroeconomic factors such as inflation, interest rate, GDP growth rates, unemployment rate , etc., and changes in the stock indexes in Lebanon. Statistical modeling and forecasting of stock market performance, taking into account these limitations, will make it possible to obtain reasonable estimations either for investors and financial market players or for further development of the whole Lebanese economy.

The high requirements for forecast results and the uncertainty of the situation have led to the need for adaptive forecasting methods and will prompt a significant amount of further additional research on the Lebanese stock market.

\section{References}

1. Park, C. H., \& Scott, H. I. (2007). What do we know about the profitability of technical analysis? Journal of Economic Surveys, Vol. 21, 786-826. Retrieved from https://doi.org/10.1111/j.1467-6419.2007.00519.x

2. Nguyen, T. H., Kiyoaki, S., \& Julien V. (2015). Sentiment Analysis on Social Media for Stock Movement Prediction. Expert Systems with Applications, Vol. 42, 9603-9611. DOI: 10.1016/j.eswa.2015.07.052

3. Janssen, C., Langager, C., \& Murphy, C. (2010). The Forex Market Tutorial. A division of Valueclick, Inc. Invesetopedia. Retrieved April 23, 2020 from http://investopedia.com

4. Ou, J. A., \& Penman, S. H. (1989). Financial statement analysis and the prediction of stock return. Journal of Accounting and Economics, Vol. 11, 4, 295-329. Retrieved from https://doi.org/10.1016/01654101(89)90017-7

5. McDonald, M. (2011). Forex Simplified: Behind the Scenes of Currency Trading. (2nd ed.). USA: Marketplace Books.

6. Hu, Yo., Kang, L., Xiangzhou, Z., Lijun, S., Ngai, E. W. T., \& Mei, L. (2015). Application of evolutionary computation for rule discovery in stock algorithmic trading: A literature review. Applied Soft Computing, Vol. 36, Issue C, 534-551. Retrieved from https://doi.org/10.1016/j.asoc.2015.07.008

7. BDL STOCK IX (BDLSI). Investing.com. Retrieved from https://www.investing.com/indices/bdlstock-ix

8. Murphy, J. (1999). Technical Analysis of the Financial Markets: A Comprehensive Guide to Trading Methods and Applications. New York: New York Institute of Finance. 
9. Hsu, P. -H., \& Taylor, M. P. (2013). Forty Years, Thirty Currencies and 21,000 Trading Rules: A Largescale, Data-snooping Robust Analysis of Technical Trading in the Foreign Exchange Market. Retrieved from http://dx.doi.org/10.2139/ssrn.2517125.

10. Bonga, W. G. (2015). The Need for Efficient Investment: Fundamental Analysis and Technical Analysis. Social Science Research Network. Retrieved from http://dx.doi.org/10.2139/ssrn.2593315

11. Brock, W., Lakonishok, J., \& LeBaron, B. (1992). Simple Technical Trading Rules and the Stochastic Properties of Stock Returns. The Journal of Finance, Vol. 47, 5, 1731-1764. Retrieved from https://doi. org/10.2307/2328994

12. Hejase, A. J., El-Hokayem, J. S., Hejase, H. J. (2016). Technical analysis in practice: Exploring Lebanese Stock Market. The International Journal of Business and Management Research, Vol. 9, 1, 28-43. Retrieved from https://www.researchgate.net/publication/312032406_Technical_analysis_in_practice_Exploring_ Lebanese_stock_market

13. Fu, T., Chung, F., Luk, R. W. P., \& Chak-man, Ng. (2005). Preventing Meaningless Stock Time Series Pattern Discovery by Changing Perceptually Important Point Detection. Proceedings from Fuzzy Systems and Knowledge Discovery: Second International Conference (August 27-29). Changsha, China; SpringerVerlag Berlin Heidelberg. Part 1. Pp. 1171-1174. DOI:10.1007/11539506_146

14. Kabašinskas, A. (2007). Statistical analysis of financial markets and methods of statistical modeling. Candidate's thesis. Vilnius. Retrieved from https://www.mii.lt/files/doc/lt/doktorantura/apgintos disertacijos/mii_dis_san_2008_akabasinskas.pdf

15. Banerjee, D. (2014). Forecasting of Indian stock market using time series ARIMA model. Proceedings from Business and Information Management (ICBIM): 2nd International Conference (January 9-11). (pp. 131-135). DOI: 10.1109/ICBIM.2014.6970973

16. Site of Beirut Stock Exchange. Yearly Reports. wrw .bse.com.lb. Retrieved from http://www.bse.com. lb/Market/HistoricalData/YearlyBulletins/tabid/154/Default.aspx

17. Cœuré, B. (2015). The international role of the euro: concepts, empirics and prospects. Speech at Saint Joseph University, Beirut. October 2, 2015. ecb.europa.eu. Retrieved from https://www.ecb.europa.eu/press/ key/date/2015/html/sp151002.en.html

18. Cromwell, J. B., Labys, W. C., \& Terraza, M. (1994). Univariate Tests for Time Series Models. SAGE Publications. DOI: Retrieved from https://dx.doi.org/10.4135/9781412986458

\section{Н. В. Агабекова,}

Dr. habil., доцент, завідувачка кафедри статистики,

E-mail:agabnin@mail.ru

ORCID: https://orcid.org/0000-0002-4315-7177;

А. Н. А. Абдо,

аспірант,

E-mail: nasserdineabdo@gmail.com

ORCID: https://orcid.org/0000-0002-4092-1037;

Заклад освіти “Білоруський державний економічний університет” (Мінск, Білорусь)

\section{Економіко-статистичний аналіз індикаторів фондового ринку Лівану}

Аналіз фінансових процесів є важливою галуззю статистики, яка наразі швидко розвивається. Статистичний аналіз - це комбінований аналіз. Статистична методологія передбачає виявлення кількісних закономірностей у динаміці та взаємозв'язку соціально-економічних явищ. Важливою особливістю статистичної методології є врахування специфіки досліджень, для яких вона призначена, що виражається в нерозривному зв'язку кількісного аналізу зі встановленням якісної унікальності об'єктів у конкретних історичних умовах місця і часу. Використання методів математичної статистики та інших розділів математики (зокрема прикладних) стає технічним інструментом реалізації.

Ліванський фондовий ринок сьогодні неактивний і скорочується. Історично Ліван мав доволі динамічний ринок капіталу на Близькому Сході до того, як фондова біржа була закрита на двадцять років через громадянську війну (1975-1995рр.). 3 моменту відкриття в 1996 році фондовий ринок скорочувався. Заснування компанії Solidere наприкінці 1990-х рр. і відродження комерційних банків на якийсь час активізували фондовий ринок, перш ніж волатильність ринку вщухла.

Проаналізовано зміну основних індикаторів фондового ринку Лівану за період 2012-2019рр. Дослідження пропонує статистичну модель декомпозиції часових рядів, що дозволяє виявити тренд, се- 
зонний, циклічний і випадковий компоненти. Результати моделювання дозволили встановити закономірності зміни цін акцій трьох провідних підприємств, які представляють будівельний, промисловий і банківський сектори ліванської економіки. Виміряно тривалість і глибину малих циклів у динамічних рядах досліджуваних показників. Встановлено, що глибина циклічних коливань збільшується при зниженні цін на акції будівельних і промислових підприємств Лівану під впливом як економічних, так і політичних процесів. Водночас циклічність в цінах на акції банківського сектору країни менш виражена і переважно визначається змінами, що відбувалися в економіці

Ключові слова: фондовий ринок, статистичний аналіз, декомпозиція часових рядів, малі иикли, компоненти часових рядів, економіка Лівану.

Bibliographic description for quoting:

Agabekova, N. V., \& Abdo, A. N. A. (2021). Economic and Statistical Analysis of Stock Market Performance in Lebanon. Statystyka Ukrainy - Statistics of Ukraine, 1, 75-84. Doi: 10.31767/su.1(92)2021.01.08.

Бібліографічний опис для цитування:

Агабекова Н. В., Абдо А. Н. А. Економіко-статистичний аналіз індикаторів фондового ринку Лівану (публікується англійською мовою). Статистика Украӥни. 2021. № 1. С. 75-84.

Doi: 10.31767/su.1(92)2021.01.09.

\section{ШІановні читачі!}

Ви маєте можливість оформити редакційну передплату за реквізитами:

Одержувач платежу: Національна академія статистики, обліку та аудиту

Код ЄДРПОУ 04837462 ,

Рахунок одержувача UA923206490000026000052638100, МФО 320649

Установа банку: ПАТ «ПриватБанк» м. Києва.

Вид платежу: за журнал «Статистика України».

Вартість редакційної передплати: 150 грн за номер.

Прізвище та адресу доставки повідомляйте на e-mail: statukraine_edit@ukr.net

або за телефоном: (044) 486-36-48. 